\title{
The Nexus Between Income and Foreign Direct Investment: Evidence from the Gambia
}

\author{
Alfusainey Touray ${ }^{1,2,3}$ \\ ${ }^{1}$ College of Management \& Information Technology, American International University, Banjul, The Gambia \\ ${ }^{2}$ Gambia Investment and Export Promotion Agency (GIEPA), Serrekunda, The Gambia \\ ${ }^{3}$ Institute of Social Sciences, Department of Economics, Marmara University, Istanbul, Turkey
}

Email address:

tourayalfusainey@hotmail.com

\section{To cite this article:}

Alfusainey Touray. The Nexus Between Income and Foreign Direct Investment: Evidence from the Gambia. Journal of World Economic Research. Vol. 9, No. 1, 2020, pp. 1-9. doi: 10.11648/j.jwer.20200901.11

Received: June 24, 2019; Accepted: September 9, 2019; Published: January 4, 2020

\begin{abstract}
The purpose of this study is to empirically examine the dynamic impact of the stock of foreign direct investment (FDI) inflows on the aggregate income of The Gambia. In order to find the dynamic nexus, the ARDL model was used to capture both short-run and the long-run impact of FDI inflows. The result shows that FDI has a negative impact on income in the shortrun. The bounds testing for cointegration showed that there is a long-run level relationship between income and FDI inflows, and the impact of FDI inflows on income in the long-run is positive. In order to examine the possible reason why FDI inflows have a different impact in the short-run and the long-run, the study empirically investigates how the interaction of FDI inflows and domestic investment affects income. The results showed that in the short-run FDI inflows crowded-out domestic investment and this led to FDI inflows to have a negative impact on income in the short-run. Moreover, the results also showed that in the longrun the FDI inflows complemented domestic investment and this led to FDI inflows to have a positive impact on aggregate income in the long-run. The conclusion drawn from this study is that the net impact of FDI inflows on the aggregate income of The Gambia depends on the degree of complementarity and substitution between FDI inflows and domestic investment.
\end{abstract}

Keywords: Foreign Direct Investment, ARDL, Bounds Testing, Cointegration, Aggregate Income, The Gambia

\section{Introduction}

It is due to growth models putting emphasize on the importance of capital accumulation and technological progress in determining the income of a country that most governments and its policy makers find ways to increase domestic savings so that it can be channeled to domestic investment [1]. Unfortunately, sometimes domestic savings are not enough; hence, the government and its policy makers make policies to attract foreign direct investment (FDI). These changes in national policies to attract FDI are carried out due to the notion among a lot of academics and policy makers that FDI is a source of economic growth and development in a host country through the transfer of not only physical capital but also technology [2].

However, in the empirical literature the impact of FDI on the income of a host country is ambiguous. The impact of the FDI on the host country's economy is believed to be conditional upon on whether the internal domestic conditions of a host country such as political and economic conditions are favourable [3]. Ref [4] has stated that the impact of FDI on the host country's income depends on the interaction between FDI and the domestic investment. If FDI has a positive impact on domestic investment then FDI would have a positive impact on the income and vice-versa. Ref [2] has argued that the impact of the FDI on the growth of the host country depends on the level of human capital in the host country. Thus, from the theoretical literature, FDI inflows alone cannot have an impact on the host country income; certain internal conditions must be in place before a host country can derive a maximum benefit from FDI inflows.

It is due to this ambiguity in the theoretical literature that this study examines whether there is an empirical nexus between stock of FDI inflows and the income of The Gambia. The result shows that the stock of FDI inflows have a negative impact in the short-run and the bound testing for cointegration shows that there is a long-run level relationship 
between income, stock of FDI inflows and other variables used in the study. The empirical result shows that in the longrun stock of FDI inflows have positive impacts on income. The question that arises from this empirical result is that why the stock of FDI inflows have different impact in the shortrun and in the long-run? To find the answer to this question the study tested [4] ${ }^{1}$ hypothesis, that the impact of FDI in the recipient country depends on the degree of complementarity and substitution between FDI and domestic investment (DI). Thus, the study empirically examines how the interaction of FDI inflows and domestic investment affect income in both short-run and in the long-run. The results show that in the short-run FDI inflows crowded-out domestic investment, a reason why FDI inflows have a negative impact on income in the short-run. However, in the long-run FDI inflows complement domestic investment, a reason why FDI has a positive impact on income in the long-run.

There are many empirical studies on the nexus between FDI and income of a host country; however, the novelty of this study is the empirical testing of [4] hypothesis in The Gambia. The empirical results show that [4] hypothesis holds in The Gambia, that is, the net impact of FDI in the recipient country depends on the linkage between FDI (foreign investors) and domestic investment (local firms). Another mild contribution is the methodology used, ARDL and bound testing for cointegration. ARDL and bound testing can deal with endogeniety problem [4] that previous studied suffered from.

The rest of study is divided as follows; section 2 briefly reviews the literature on the link between FDI and the income of a host country. Section 3 briefly explains the data used and the methodology employed to study the empirical link between FDI inflows and the income. Section 4 gives the empirical results, section 5 analyse the empirical results, and section 6 concludes the paper.

\section{Literature Review}

Multinational corporations (MTNs) after establishing subsidiary in a host country, they transfer technology and knowledge that they used in their parent company to the host country. Thus, the FDI has a positive impact on the host country state of technology and knowledge which in turn have an impact on the economic growth of the host country [5]. The partnership of MTNs and the local firm's leads to local firms supplying product or services on behalf of MTNs, hence, MTNs ensure that their local partners are equipped with most recent technology in their production process [6]. The transfer of the technology comes from the training and technical assistance the MTNs give to their local partners [3]. Ref [7] stated that the introduction of new production processes and the new products are the most noticeable changes brought by MTNs or FDI. However, the transfer of technology to the host country is not without negative consequences. The local firms

1 “....Although FDI is expected to boost long-run growth in the recipient economy via technological upgrading and knowledge spill overs, it is shown that the extent to which FDI is growth-enhancing depends on the degree of complementarity and substitution between FDI and domestic investment" have to pay royalties on some of the newly introduced technologies and this outflow can have a negative impact on the host country balance of payment. Moreover, the host country dependence on the foreign technology can cause decline in R\&D in the host country.

FDI can lead to formation of human resources in the host country. FDI is a channel through which advance technology to a host country is transferred, but for this technology to be used efficiently, the labor force should be highly skilled which is not the case in many host countries. Thus, MTNs provide both formal and informal trainings to upgrade the skills of the domestic labor force [2]. According to [7], some of these local workers trained by MTNs go on to establish their own businesses and they transfer the human capital or training they received from MTNs to the workers they hire to work in their businesses. This increases the capacity of the labor force and upgrades the human capital in the host country. However, FDI could also lead to increase in the unemployment as technology or machines mean fewer workers in the production process [3].

MTNs help the domestic firms to participate in the world markets through including local partners in their global strategies [3]. The partnership local firms formed with the MTNs help them to become subcontractors of MTNs and this enable them to produce goods and services that can be exported and this induces growth in the host country [7]. In case FDI is made in the assembly lines, both import of inputs and the export of the final product of the host country will increase. The increased in the export of the domestic firms will in turn increase their productivity [8]. The opening of a host country economy to the world is not without negative impact. According to [9] FDI has more impact on import than the export, thus, it net impact on a host county balance of payment is negative, and in a situation where the goal of MTNs is to supply the domestic market, FDI will not stimulate export. Ref [3] and [10] outlined that FDI can also affect the balance of payment if the profit made by MTNs are repatriated to their home countries. According to [11], the repatriation of the profit can even be worse when the funds that financed the FDI are obtained from the host country local financial markets.

FDI increases competition in the host country. FDI increases the number of firms operating in the host country. For the domestic firms to keep their share of the market they have to stand up to the foreign firms and this leads to better allocation of scare resources and improves the productivity of domestic firms [12]. Moreover, the competition forces the local firms to carry out R\&D activities [7]. The responds of domestic firms to this competition lead to improvement in their technology, accumulation of equipment and training of their employees [13, 14]. However, if local firms cannot stand this competition, then FDI can crowd-out domestic firms in all the local markets [15].

According to [3], if FDI is achieved via takeovers or privatization, the new methods of production and policies are incorporated into the firm that is being taken over or privatized, and the adoption of these new policies and procedures is being complemented by bringing in new skilled 
workers from the other subsidiaries of MTNs. If the new changes, policies and procedure are more efficient than the existing ones before, there will be efficiency gains. The structure of the local firms can also suffer if they voluntarily adopt the policies and procedures of MTNs with the belief that they are more efficient relative to theirs [16]. Ref [7] pointed out that foreign firms enter into markets with high entry barriers where local firms cannot. This causes change in the structure of the local economy via eradicating or minimizing monopolies.

The autonomy of the local authorities may be at threat [17]. The MTNs have a large impact on the labour force of a host country via their hiring and layoffs, and this may give them an advantage to influence the political and economic process in a host country [18]. The MTNs can put pressures on local authorities to make policies that are beneficial to their operations, but at the expense of the economic growth of a host country $[15,18]$.

The conclusion one can draw from the literature is that the impact of FDI on the economy of the host country works through many channels and whether it has negative or positive impact on the economy of the host country would depend on whether positive channels dominates the negative channels. These channels are shown in Table 1 below.

Table 1. The Channels through Which FDI Affects Economic Growth.

\begin{tabular}{lll}
\hline \multirow{2}{*}{ Channels } & \multicolumn{2}{l}{ The Impact On The Host Country Economy } \\
\cline { 2 - 3 } & Positive Impact & Negative Impact \\
\hline Transfer of new technology \& knowledge & $\mathrm{X}$ & $\mathrm{X}$ \\
The formation of human resources & $\mathrm{X}$ & $\mathrm{X}$ \\
Integration into the global economy & $\mathrm{X}$ & $\mathrm{X}$ \\
Increased in competition & $\mathrm{X}$ & $\mathrm{X}$ \\
Firms development \& restructuring & $\mathrm{X}$ & $\mathrm{X}$ \\
Economic implementation & & $\mathrm{X}$ \\
\hline
\end{tabular}

Source: [19] \& [3]

\section{Method}

The study used annual data from 1980 to 2013. The time series used were aggregate income (Y), domestic investment (DI), export (X), import (I), and stock of FDI inflows (FDI). The source of aggregate income, domestic investment, export, and import was the Word Bank Development Indicator [20] while the stock of FDI inflows was taken from the statistical database of United Nation Conference on Trade and Development [21]. The domestic gross fixed capital formation was used as a proxy for domestic investment in this study.

This study defined aggregate income as a function of domestic investment, stock of FDI inflows, export, and import. This is shown in equation (1) below;

$$
Y=f(D I, F D I, X, I)
$$

Equation (1) was transformed to econometic model as in equation (2);

$$
Y_{t}=\beta_{0}+\beta_{1} D I_{t}+\beta_{2} F D I_{t}+\beta_{3} I_{t}+\beta_{4} X_{t}+u_{t}
$$

The objective of this study is to find the dynamic nexus between income and FDI, that is, to find the impact of FDI on income in both short-run and long-run. Thus, equation (2) was transformed in to a model that could capture the short-run and long-run impact of FDI on the aggregate income. One of the models that capture the dynamic relationship between economic variables is ARDL (autoregressive-Distributed Lag) model. The ARDL model can be derivred from the traditional Error Correction Model (ECM) in equation (3).

$$
\Delta Y_{t}=\theta_{0}+\sum_{i=1}^{k} \theta_{i} \Delta Y_{t-i}+\sum_{i=0}^{k} \theta_{i} \Delta D I_{t-i}+\sum_{i=0}^{k} \theta_{i} \Delta F D I_{t-i}+\sum_{i=0}^{k} \theta_{i} \Delta X_{t-i}+\sum_{i=0}^{k} \theta_{i} \Delta I_{t-i}+\gamma E C_{t-1}+u_{t}
$$

Where;

$$
E C_{t-1}=Y_{t-1}-\beta_{0}-\beta_{1} D I_{t-1}-\beta_{2} F D I_{t-1}-\beta_{3} I_{t-1}-\beta_{4} X_{t-1}
$$

Equations (3) and (4) were used to derive the unrestricted error correction model in equation (5) below, this represents the ARDL model. The impact of independent variables on the

$$
\begin{aligned}
\Delta Y_{t}= & \beta_{0}+\sum_{i=1}^{n} \beta_{1 i} \Delta Y_{t-i}+\sum_{i=0}^{n} \beta_{2 i} \Delta D I_{t-i}+\sum_{i=0}^{n} \beta_{3 i} \Delta F D I_{t-i}+\sum_{i=0}^{n} \beta_{4 i} \Delta X_{t-i} \\
& +\sum_{i=0}^{n} \beta_{5 i} \Delta I_{t-i}+\delta_{6} Y_{t-1}+\delta_{7} D I_{t-1}+\delta_{8} F D I_{t-1}+\delta_{9} X_{t-1}+\delta_{10} I_{t-1}+u_{t}
\end{aligned}
$$

Before the long-run impact of a variable on another variable is determined, there must be an existence of cointegration, that is, the time series must have long-run level relationship. Bound testing for cointegration was applied to equation (5) to determine whether there is cointegration between the variables [22]. Bounds testing unlike other methods of cointegration, it can be employed regardless of the level of stationary of the regressors as long as they are not integrated above I(1). The approach can be employed regardless of whether the regressors are purely $\mathrm{I}(0), \mathrm{I}(1)$, or a mixture of $\mathrm{I}(0)$ and $\mathrm{I}(1)$. Moreover, the approach is suitable for 
small sample size and the problem of endogeneity is minimized as long as the ARDL model is free from residual correlations [23].

Bound testing for cointegration requires that the variables in equation (5) should not be integrated above first difference, I (1). Thus, the first step in bound testing for the presence of cointegration between economic time-series is to test the level of integration of the variables using one of the unit root testing methods. This study used ADF unit root test. When using ADF test for unit root, one has to make two choices. First, the researcher has to decide which model or equation one has to choose among equations (6), (7), and (8). Second, once has to decide the optimal lag length. The trick of choosing the optimal lag length is to choose a lag that eradicates serial correlation in the residuals in equations (6), (7), and (8).

$$
\begin{gathered}
\Delta y_{t}=\gamma y_{t-1}+\sum_{i=1}^{\rho} \beta_{i} \Delta y_{t-1}+u_{t} \\
\Delta y_{t}=\propto_{0}+\gamma y_{t-1}+\sum_{i=1}^{\rho} \beta_{i} \Delta y_{t-1}+u_{t} \\
\Delta y_{t}=\propto_{0}+\gamma y_{t-1}+a_{2} t+\sum_{i=1}^{\rho} \beta_{i} \Delta y_{t-1}+u_{t}
\end{gathered}
$$

After confirming that none of the variables is integrated above first difference I(1), the next step before the estimation of the equation (5) is to determine the appropriate lag level structure for each variable in equation (3.5). The appropriate lag for each variable is determined using, "information criteria" such as AIC, SC (BIC), HQ, etc. Moreover, another requirement imposed by bound testing methodology of [22] is that the errors $\left(u_{t}\right)$ of equation (5) must be serially independent. Once equation (5) is estimated one of the diagnostic tests for serially independent such as LM test should be used to test the null hypothesis that the errors are serially independent against alternative hypothesis that errors are not serially independent. Bound testing for cointegration also requires that the model or equation (5) is dynamic stable since it has autoregressive structure. The study followed the tradition in testing the dynamic stability of equation (5) by using CUSUM and CUSUMSQ stability tests [24]. If equation (5) meets all the aforementioned conditions above, the bound testing is performed on equation (5).

The bound testing is based on Fisher statistics (F-test) to test the presence of long-run level relationship. The F-test is used to test the joint significance of lagged levels of the independent variables in equation (5). The null hypothesis, (there is no cointegration) is tested against alternative hypothesis (there is cointegration). Mathematically, this can be stated as;

$H_{0}: \delta_{7}=\delta_{8}=\delta_{9}=\delta_{10}=0 \quad$ (Null Hypothesis, no cointegration)

$H_{A}: \delta_{7} \neq \delta_{8} \neq \delta_{9} \neq \delta_{10} \neq 0$ (Alternative hypothesis, there is cointegration)

The decision to reject or accept the null hypothesis is based on comparing the F-statistic provided by Wald test and the critical values for the F-test given by [22]. If the F-statistic is greater than the upper critical bound value, the null hypothesis is rejected. On the contrary, if the F-statistic is less than the lower critical bound value, the null hypothesis is accepted [23].

\section{Empirical Results}

Bound testing requires that no variable is integrated above $\mathrm{I}(1)$, hence, ADF unit root test was used to test the stationary of the variables $[25,26]$. Table 2 shows the result of ADF unit root test at level using different models. Table 2 shows that all the series are non-stationary at level except aggregate output, Y, under equation (8), constant and trend. To ensure that none of the variables was integrated above I (1), ADF test was carried out at first difference and the result is presented in Table 3, and the results show that none of the variables is integrated above I (1) regardless of which model

\begin{tabular}{|c|c|c|c|c|c|c|c|}
\hline \multirow{3}{*}{ Variables } & \multirow{2}{*}{\multicolumn{2}{|c|}{$\begin{array}{l}\text { None } \\
\text { Model (3.6) }\end{array}$}} & \multirow{2}{*}{\multicolumn{2}{|c|}{$\begin{array}{l}\text { Constant } \\
\text { Model (3.7) }\end{array}$}} & \multicolumn{2}{|c|}{ Constant \&Trend } & \multirow{3}{*}{ SIC lag } \\
\hline & & & & & \multicolumn{2}{|c|}{ Model (3.8) } & \\
\hline & t-stats & P-value & t-stats & P-value & t-stats & P-value & \\
\hline $\mathrm{Y}$ & 6.242768 & 1.0000 & -0.090216 & 0.9425 & $-3.9127^{*}$ & 0.0227 & 1 \\
\hline DI & 0.836794 & 0.8871 & -0.976114 & 0.7501 & -0.322739 & 0.0966 & 1 \\
\hline FDI & 2.107609 & 0.9900 & -0.301052 & 0.9143 & -2.490648 & 0.3303 & 1 \\
\hline$X$ & 0.678814 & 0.8575 & $-3.2953^{*}$ & 0.0238 & -3.142166 & 0.1147 & 3 \\
\hline I & -0.215165 & 0.6011 & -2.679930 & 0.0882 & -2.858817 & 0.1880 & 1 \\
\hline
\end{tabular}
is used so the condition of bounds testing was met.

Table 2. ADF Unit Root Test (Level).

Note: Sample level 1980-2013. The critical values at 5\% significance for Models (3.6)), (3.7) and (3.8) are $-1.94,-2.86$, and -3.41 respectively. The optimal lag

\begin{tabular}{|c|c|c|c|c|c|c|c|}
\hline \multirow{3}{*}{ Variables } & \multirow{3}{*}{\begin{tabular}{|l|} 
None \\
Model (1) \\
t-stats
\end{tabular}} & & \multirow{2}{*}{\begin{tabular}{|l|} 
Constant \\
Model (2) \\
\end{tabular}} & & \multicolumn{2}{|c|}{ Constant \& Trend } & \multirow{3}{*}{ SIC lag } \\
\hline & & & & & \multicolumn{2}{|c|}{ Model (3) } & \\
\hline & & P-value & t-stats & P-value & t-stats & P-value & \\
\hline $\mathrm{Y}$ & $-3.39443 *$ & 0.0013 & $-6.71926^{*}$ & 0.0000 & $-6.61153 *$ & 0.0000 & 0 \\
\hline DI & $-6.69593 *$ & 0.0000 & $-6.83074 *$ & 0.0000 & $-6.70786^{*}$ & 0.0000 & 0 \\
\hline FDI & $-4.71964 *$ & 0.0000 & $-5.23801 *$ & 0.0002 & $-5.16658 *$ & 0.0011 & 0 \\
\hline $\mathrm{X}$ & $-4.55272 *$ & 0.0000 & $-4.49670 *$ & 0.0011 & $-4.43470^{*}$ & 0.0068 & 0 \\
\hline I & $-6.43904 *$ & 0.0000 & $-6.33791 *$ & 0.0000 & $-6.50247 *$ & 0.0000 & 0 \\
\hline
\end{tabular}
lengths were chosen according to SIC. * means significant at $5 \%$ level.

Table 3. ADF Unit Root Test (First Difference).

Note: Sample level 1980-2013. The critical values at 5\% significance for Models (3.6)), (3.7) and (3.8) are -1.94, -2.86, and -3.41 respectively. The optimal lag lengths were chosen according to SIC. * means significant at $5 \%$ level. 
After confirming the stationary of the series, equation (5) was estimated. The results give short-run coefficients, bounds testing for cointegration, and long-run coefficients which are presented in Tables 4, 5, and 6, respectively.

Table 4. Short-Run Coefficients.

\begin{tabular}{lllll}
\hline Variables & Coefficients & $\begin{array}{l}\text { Std. } \\
\text { Errors }\end{array}$ & t-Statistics & Prob \\
\hline D (DI) & 0.091492 & 0.025694 & $3.560848 *$ & 0.0031 \\
D (FDI) & -0.124961 & 0.037327 & $-3.347764 *$ & 0.0048 \\
D (FDI (-1)) & -0.503425 & 0.077046 & $-6.534074 *$ & 0.0000 \\
D (FDI (-2)) & -0.234297 & 0.061453 & $-3.812613 *$ & 0.0019 \\
D (FDI (-3)) & -0.218331 & 0.049860 & $-4.378861 *$ & 0.0006 \\
D (X) & 0.066833 & 0.022781 & $2.933703 *$ & 0.0109 \\
D (X (-1)) & -0.057956 & 0.033288 & -1.741083 & 0.1038 \\
D (I) & 0.016064 & 0.029041 & 0.553166 & 0.5889 \\
D (I (-1)) & 0.262583 & 0.048570 & $5.406232 *$ & 0.0001 \\
D (I (-2)) & 0.103828 & 0.032522 & $3.192597 *$ & 0.0065 \\
ET ${ }_{\text {C-1 }}$ & -0.707857 & 0.074458 & $-9.506763 *$ & 0.0000 \\
\hline
\end{tabular}

Note: The estimated model is based on AIC with the lag orders of $(1,1,4,2$, $3)$ * means the coefficient is statistically significant at $5 \%$ level.

The result from Table 4 shows that in the short-run the stock of FDI inflows has a negative impact on the income not only in the current period but also in the past three periods.

Table 5. Cointegration Test.

\begin{tabular}{lll}
\hline Dependent Variable & F-statistics & Decision \\
\hline$F_{Y}(Y \backslash D I, F D I,, X, I)$ & 11.09912 & There is cointegration \\
\hline
\end{tabular}

Note: The upper critical bound values at $1 \%, 2.5 \%, 5 \%$, and $10 \%$ significance level are 4.37, 3.87, 3.49, and 3.09 respectively. Pesaran et al. (2001), table CI (ii).

From Table 5, the F-statistics (11.099) is greater than the upper critical bound values regardless of the level of significance; hence, there exist a long-run level relationship between the variables.
Table 6. The long-Run coefficients.

\begin{tabular}{lllll}
\hline Variables & Coefficients & $\begin{array}{l}\text { Std. } \\
\text { Errors }\end{array}$ & t-Statistics & Prob \\
\hline DI & 0.188026 & 0.058721 & $3.202024^{*}$ & 0.0064 \\
FDI & 0.753359 & 0.046541 & $16.186964^{*}$ & 0.0000 \\
X & 0.402762 & 0.040177 & $10.024677^{*}$ & 0.0000 \\
I & -0.477107 & 0.088997 & $-5.360918^{*}$ & 0.0001 \\
C & 14.226313 & 1.263120 & $11.262836^{*}$ & 0.0000 \\
\hline
\end{tabular}

Note: The estimated model is based on AIC with the lag orders of $(1,1,4,2$, $3)$. ${ }^{*}$ means the coefficient is statistically significant at $5 \%$ level.

The impact of the stock of FDI inflows on income in the long-run is positive and it is shown in Table 6. The empirical results show that the impact of the stock of FDI inflows in The Gambia depends on the time period, that is, short-run and the long-run. An increase in the stock of FDI inflows to The Gambia, on average, the income of The Gambia will immediately reduce by 0.13 percent in the short-run while in the long-run one percent increase in the stock of FDI inflows will increase income by 0.75 percent.

The diagnostic test results for equation (5) for short-run coefficients are displayed in Table 7. The model passed all the standard diagnostic tests. The figures for CUSUM and CUSMQ tests are presented in figures 1 and 2 below. From both figures, the plots of both statistics are well within the critical bound; this means that all the coefficients in the error correction model are stable.

Table 7. Diagnostic Tests.

\begin{tabular}{lll}
\hline Tests & F-statistic & P-value \\
\hline Normality (Jarque-Bera) & 1.367322 & 0.5048 \\
Serial Correlation (LM tests) & 0.468868 & 0.6367 \\
Heteroskedasticity & 0.547734 & 0.8702 \\
Ramsey RESET & 1.173663 & 0.2983 \\
\hline
\end{tabular}

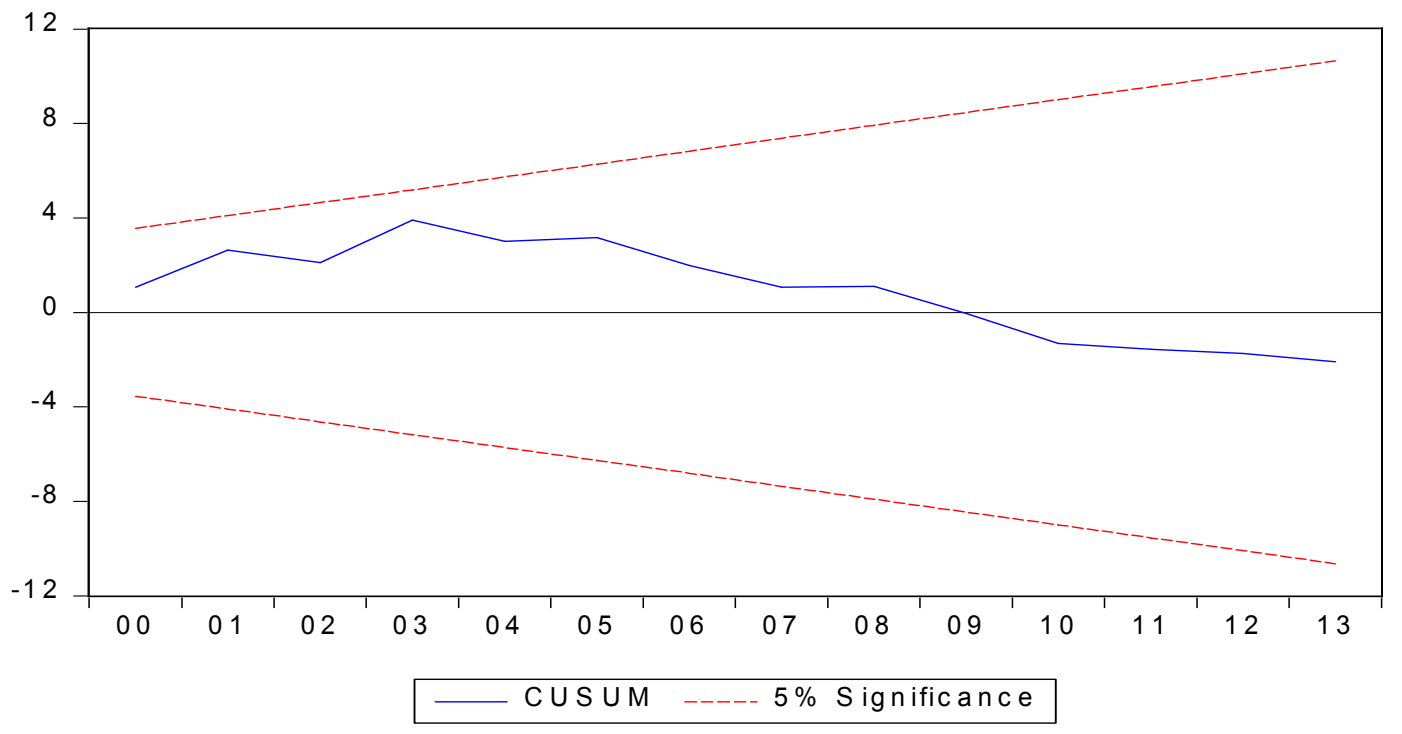

Figure 1. Plot of CUSM Test. 


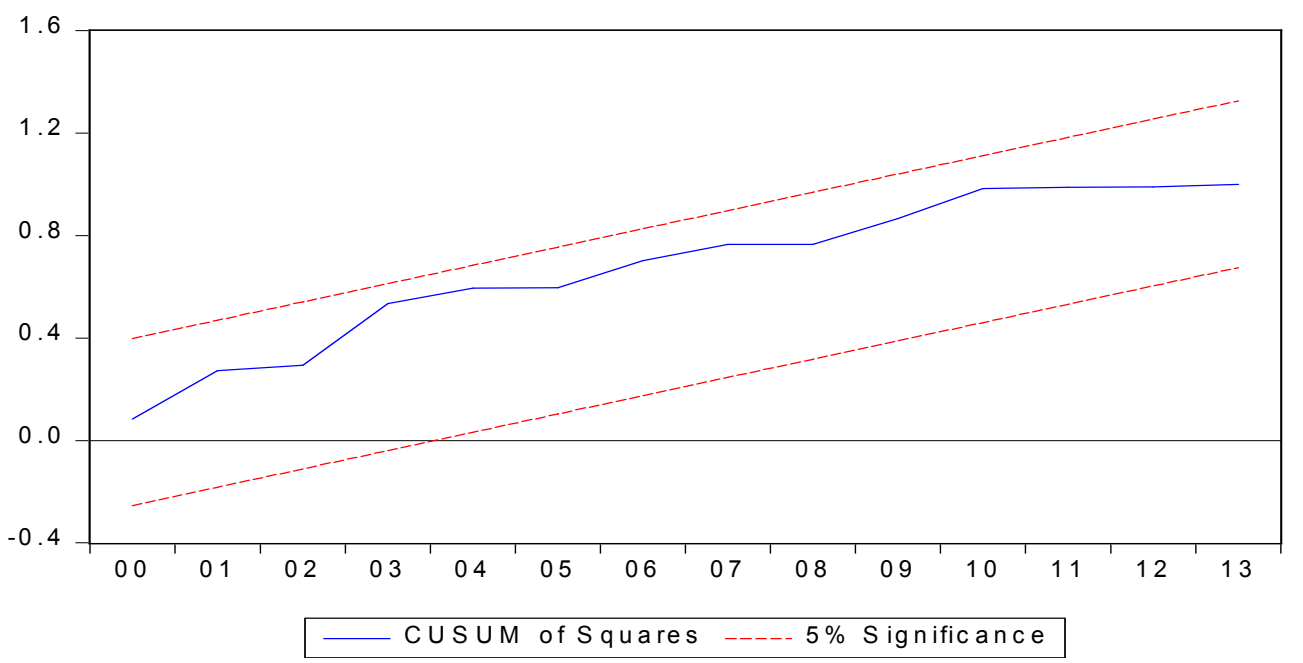

Figure 2. Plot of CUSUMQ Test.

\section{Discussion}

The results show that the stocks of FDI inflows have a negative impact in the short-run and a positive impact in the long-run. The question that arises from these empirical results is that why FDI has negative impact in the short-run and positive impact in the long-run? The answer to this question can be found in a study conducted by [4] where he stated that;

"....Although FDI is expected to boost long-run growth in the recipient economy via technological upgrading and knowledge spillovers, it is shown that the extent to which FDI is growth- enhancing depends on the degree of complementarity and substitution between FDI and domestic investment" [4]

Thus, in order to find the reason behind the different impacts of the stock of FDI inflows in The Gambia, this study empirically examines [4] hypothesis that the impact of FDI in the recipient economy depends on the complementarity and substitution between FDI and domestic investment, that is, this study examines how the interaction of domestic investment and stock of FDI inflows (DI*FDI) affects the income in The Gambia. This interaction is modelled below in equation (3.9);

$$
\begin{aligned}
\Delta Y_{t}= & \beta_{0}+\sum_{i=1}^{n 1} \alpha_{1 i} \Delta Y_{t-i}+\sum_{i=0}^{n 2} \alpha_{2 i} \Delta(D I * F D I)_{t-i}+\sum_{i=0}^{n 3} \alpha_{3 i} \Delta X_{t-i}+\sum_{i=0}^{n 4} \alpha_{4 i} \Delta I_{t-i} \\
& +\partial_{5} Y_{t-1}+\partial_{6}(D I * F D I)_{t-1}+\partial_{7} X_{t-1}+\partial_{8} I_{t-1}+u_{t}
\end{aligned}
$$

The main focus in equation (9) is the signs of the interaction coefficients $\alpha_{2 i}$ (short-run coefficient) and $\partial_{6}$ (long-run coefficient). If $\alpha_{2 i}$ has a negative sign, it means FDI substitutes or crowd-outs DI in the short-run, and the interaction of FDI and DI in the short-run has a negative impact on income and vice-versa. If $\partial_{6}$ has a negative sign, it means FDI substitutes or crowd-outs DI in the long-run, and the interaction of FDI and DI in the long-run has a negative impact on income and vice-versa.

Equation (9) is estimated and the results are shown in Table 8 (short-run impacts), Table 9 (cointegration) and Table 10 (long-run impacts).

Table 8. Short-Run Coefficients.

\begin{tabular}{lllll}
\hline Variables & Coefficients & Std. Errors & t-Statistics & Prob \\
\hline D (DI*FDI) & -0.3010421 & 0.0739138 & $-4.07^{*}$ & 0.001 \\
D (DI*FDI (-1)) & -0.2101803 & 0.0728203 & $-2.89^{*}$ & 0.013 \\
D (DI*FDI (-2)) & -0.1876152 & 0.0494494 & $-3.79^{*}$ & 0.002 \\
D (DI*FDI (-3)) & -0.1578277 & 0.0563442 & $-2.80^{*}$ & 0.015 \\
D (X) & -0.1882297 & 0.05382 & $-3.50^{*}$ & 0.004 \\
D (X (-1)) & -0.0226754 & 0.0472175 & -0.48 & 0.639 \\
D (X (-2)) & -0.0885237 & 0.0385558 & $-2.30^{*}$ & 0.039 \\
D (X (-3)) & -0.0745783 & 0.033652 & $-2.22^{*}$ & 0.045 \\
D (I) & 0.3862805 & 0.0973813 & $3.97 *$ & 0.002 \\
D (I(-1)) & 0.2171873 & 0.0826135 & $2.63^{*}$ & 0.021 \\
\hline
\end{tabular}

\begin{tabular}{lllll}
\hline Variables & Coefficients & Std. Errors & t-Statistics & Prob \\
\hline $\mathrm{D}(\mathrm{I}(-2))$ & 0.1972588 & 0.0658258 & $3.00^{*}$ & 0.010 \\
$\mathrm{D}(\mathrm{I}(-3))$ & 0.190116 & 0.0634873 & $2.99^{*}$ & 0.010 \\
$\mathrm{EC}_{\mathrm{T}-1}$ & -0.6420603 & 0.2035959 & $-3.15^{*}$ & 0.008 \\
\hline
\end{tabular}

Note: The estimated ARDL model is based on AIC with the lag orders of (1, $4,4,4)$ model. * means the coefficient is statistically significant at $5 \%$ level.

In Table 8 the coefficients of the interaction term is negative for all four lags, this means stock of FDI inflows substitute domestic investment in The Gambia in short-run and this ultimately led to negative impact on the income in the short-run. In the short-run the foreign investors in The Gambia crowded-out domestic investors in the financial, labour and product markets. This negative impact outweighs the other positive benefits of FDI in the short-run and the net impact on income is negative in the short-run.

Table 9. Cointegration Test (Bound Testing).

\begin{tabular}{lll}
\hline Dependent Variable & F-statistics & Decision \\
\hline$F_{Y}(Y \backslash D I * F D I,, X, I)$ & 10.426 & There is a cointegration \\
\hline
\end{tabular}

Note: The upper critical bound values at $1 \%, 2.5 \%, 5 \%$, and $10 \%$ are 4.37 , $3.87,3.49$, and 3.09 respectively. Pesaran et al. (2001), table CI (ii). 
In order to examine the impact of the interaction of stock of FDI inflows and domestic investment in the long-run, equation (9) is tested for existence of cointegration. The result in Table 9 shows that there is a cointegration since Fstatistics (10.426) is greater than the upper critical bound values at all the significance levels. Since bound testing for cointegration has confirmed that a long-run level relationship exists, equation (9) is estimated for long-run coefficients and the result is presented in Table 10 .

Table 10 shows that the coefficient of the interaction term of stock of FDI inflows and domestic investment (DI*FDI) is positive, this means the stock of FDI inflows complement domestic investment in The Gambia and the interaction of stock of FDI and domestic investment in The Gambia has a positive impact on income in the long-run. In the long-run those domestic firms that withstand the competition from foreign investors and were not crowded-out in the domestic markets learned from the foreign investors by imitating their production process and managerial methods. The imitation leads to both technological upgrading and knowledge spillovers in The Gambia, and this ultimately led to positive impact of FDI on aggregate income in the long-run.
Table 10. The long-Run coefficients.

\begin{tabular}{lllll}
\hline Variables & Coefficients & Std. Errors & t-Statistics & Prob \\
\hline DI*FDI & 0.504138 & 0.0186595 & $27.25^{*}$ & 0.000 \\
X & 0.433129 & 0.0771979 & $5.61^{*}$ & 0.000 \\
I & -0.7132269 & 0.1249293 & $-5.71^{*}$ & 0.000 \\
C & 2.932015 & 0.45274 & $6.48^{*}$ & 0.000 \\
\hline
\end{tabular}

Note: The estimated ARDL model is based on AIC with the lag orders of (1, $4,4,4)$ model. * means the coefficient is statistically significant at $5 \%$ level.

The diagnostic tests for equation (9) are shown in Table 11. The model passed all the tests, and the stability of the coefficients is confirmed by CUSUM and CUSUMQ stability tests, presented in Figure 3 and Figure 4, respectively.

Table 11. Diagnostic Tests.

\begin{tabular}{lll}
\hline Tests & F-statistic & P-value \\
\hline Normality (Jarque-Bera) & 1.042827 & 0.593681 \\
Serial Correlation (LM tests) & 0.477548 & 0.6326 \\
Heteroskedasticity & 1.335160 & 0.3029 \\
Ramsey RESET & 0.080005 & 0.7821 \\
\hline
\end{tabular}

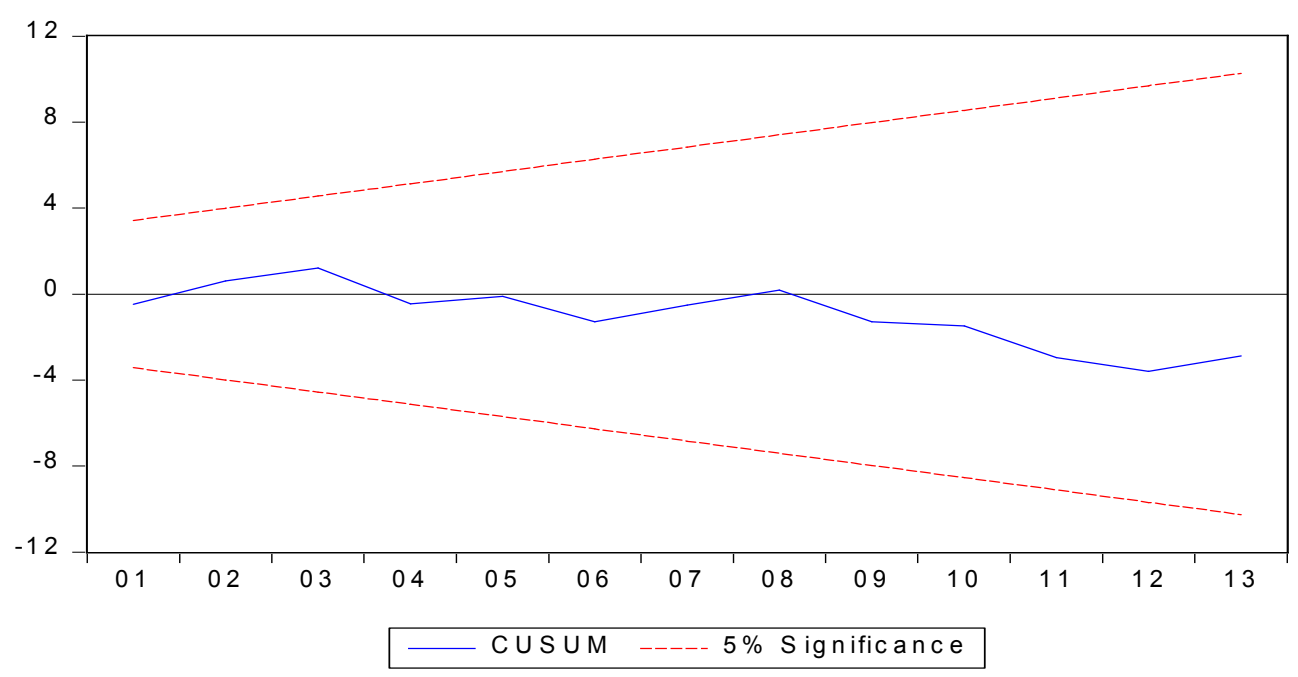

Figure 3. Plot of CUSM Test.

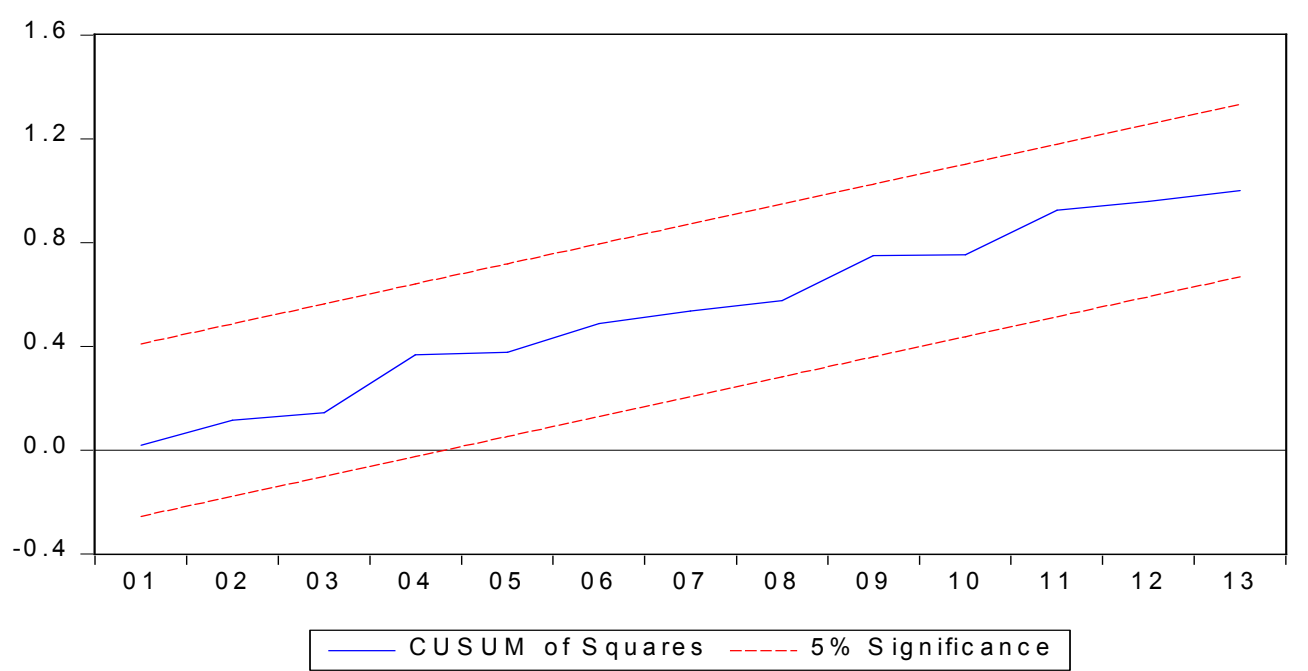

Figure 4. Plot of CUSUMQ Test. 
In conclusion, [4] hypothesis stated that the final impact of FDI on the economy of the recipient economy depends on the degree of complementarity or substitution between FDI and domestic investment holds in The Gambia empirically.

\section{Conclusion}

The study has used ARDL model in order to capture the short-run and the long-run impacts of FDI inflows in The Gambia. The empirical results have shown that the impact of FDI inflows in The Gambia depends on the time horizon, short-run or long-run. The results have shown that FDI inflows have a negative impact in the short-run and a positive impact in the long-run. The study has empirically examined the reason why FDI inflows have different impacts in different time periods, the results show that the degree of complementarity and substitution between FDI inflows and domestic investment is the reason why FDI inflows have different impact in short-run and the long-run.

In the short-run FDI inflows have crowded-out domestic investment and this negative impact outweighs the positive impacts of FDI inflows in the short-run. Thus, the overall impact of FDI inflows on the economy or aggregate income of The Gambia was negative in the short-run. However, in the long-run those local firms that withstand the competitive pressure brought by the FDI inflows, learned the new method of productions and managerial skills brought by foreign investors. These local firms have gone on to hire new workers and have trained them on new methods of production, as this continues in the economy, the economy has experienced technological upgrading and knowledge spillover in the long-run, this has caused FDI inflows to have positive impact in the long-run.

The policy implication of this is that when policy makers embark on the quest to attract FDI inflows they should simultaneously devise policies so that the net impact of FDI inflows is positive even in the short-run. One of such policies is to encourage partnership of local and the foreign firms through giving incentives for local-foreign partnerships.

This partnership of domestic and foreign firms will prevent domestic firms from being substituted from the domestic local markets. Also as domestic firms learn from their foreign counterparts, they will go on to expand businesses in the future. This means they will hire local people and trained them on current foreign industrial practices, this process leads to technological progress and spillover of knowledge in the local economy. The localforeign partnerships will help local firms to serve as agents of technological transfer between foreign investors and the local economy.

\section{References}

[1] Solow, R. (1956). A Contribution to the Theory of Economic Growth. Quarterly Journal of Economics, 65-94.
[2] Borensztein, E., De Gregorio, J., \& Lee, J.-W. (1998). How does foreign direct investment affect economic growth? Journal of International Economics, 45, 115-135.

[3] OECD. (2002). foreign direct investment for development: maximizing benefits, minimizing cost.

[4] De Mello, L. (1999). Foreign direct investment -led growth: evidence from time series and panel data. Oxford Economics Papers, 51, 133-151.

[5] Frindlay, R. (1978). Relative backwardness, direct foreign investment, and the transfer of technology: a simple dynamic model. Quarterly Journal of Economics, 92, 1-16.

[6] Rodriguez -Clare, A. (1996). Multinationals, Linkages, and economic development. American Economic Review, 86 (4), 852-873.

[7] Lim, E.-G. (2001). Determinants of, and the relation between, foreign direct investment and growth: a summary of the recent literature. International Monetary Fund Working Paper, Middle Eastern Department.

[8] Makki, S. S., Somwaru, \& Agapi. (2004). The impact of foreign direct investment and trade on economic: evidence from developing countries. American Journal of Agricultural Economics, 86 (3), 795-801.

[9] Mencinger, J. (2003). Does foreign direct investment always enhance economic growth? Kilos. Vol. 56. Issue 4, 491-58.

[10] Oztürk, I. (2007). Foreign direct investment -growth nexus: a review of the recent literature. International Journal of Applied Econometrics and Quantitative Studies, 4 (2), 79-98.

[11] Loungani, P. \& Razin Razin, A., 2001. How beneficial is foreign direct investment for developing countries. Finance and Development, a quarterly magazine of the IMF, Volume 38 , Number 2.

[12] Pessoa, A. (2007). FDI and host country productivity: a review. FEP working papers n 251, Porto: Faculdade de Economia, Universidade do Porto.

[13] Driffield, N. (2000). The impact on the domestic productivity of inwards investment into the UK. Manchester School, 69 (1), 103-119.

[14] Varamini, H., \& Vu, A. (2007). Foreign direct investment in Vietnam and its impact on economic growth. International Journal of Business Research, 7 (6), 132-139.

[15] Ram, R., \& Zhang, K. H. (2002). Foreign direct investment and economic growth: evidence from cross-country data for the 1990s. Economic Development and Cultural Change, 205215 .

[16] Hansen, H., \& Rand, J. (2006). On the casual links between FDI and growth in developing countries. World Economy, Vol. 29, Issue 1, 21-41.

[17] Duttaray, M., Dutt, A., \& Mukhopadhyay, K. (2008). Foreign direct investment and economic growth in less developed countries: an empirical study of causality and mechanisms. Applied Economics, 40, 1927-1939.

[18] Zhang, K. H. (2001b). How does foreign direct investment affect economic growth in China? Economics of Transition, 9 (3), 679-693. 
[19] Moura, R., \& Forte, R. (2010). The effects of foreign direct investment on the host country economic growth -theory and empirical evidence. FEP working papers. N. 390.

[20] WB, \& OECD. (2016). World Development Indicatırs (World Bank national accounts data, and OECD National Accounts data files.). Washington, D. C: World Bank and OECD.

[21] United Nations Conference on Trade and Development. (2016). World Investement Report. New York and Geneva: UNCTD.

[22] Pesaran, M. H., Shin, Y., \& Smith, R... (2001). Bound testing approaches to the analysis of the level relationship. Journal of Applied Econometrics, 16, 289-326.
[23] Narayan, P. K. (2005). The saving and investment nexus for China: evidence from cointegration tests. Applied Economics, 37, 1979-1990.

[24] Brown, R. L., Durbin, J., \& Evans, J. M. (1975). Techniques for testing the constancy of regression relationships over time. Journal of the Royal Statistical Society. Series B (Methodological), 149-192.

[25] Dickey, D., \& Fuller, W. (1979). Distribution of the Estimators for Autoregressive Time Series with a Unit Root. Journal of the American Statistical Association, 74, 427-31.

[26] Dickey, D..., \& Fuller, W. (1981). Likelihood Ratio Statistics for Autoregressive Time Series With a Unit Root. Econometrica, 49, 1057-72. 